\title{
NISIN REDUCES THE STAPHYLOCOCCUS AUREUS COUNT WITHOUT CHANGING THE CHARACTERISTICS OF ARTISANAL MINAS CHEESE FROM ARAXÁ
}

\section{Nisina reduz a contagem de Staphylococcus aureus sem mudar as características do Queijo Minas Artesanal de Araxá}

\author{
Denise Sobral ${ }^{1 *}$, Maximiliano Soares Pinto², Vanessa Aglaê Martins Teodoro ${ }^{3}$, \\ Renata Golin Bueno Costa ${ }^{I}$, Junio Cesar Jacinto de Paula ${ }^{1}$, Antônio Fernandes de Carvalho ${ }^{4}$ \\ Gisela de Magalhães Machado Moreira ${ }^{1}$
}

\begin{abstract}
Traditional Araxá cheese is produced with raw milk, which represents a risk to consumers' health. The action of nisin (100 IU g ${ }^{-1}$ and $\left.400 \mathrm{IU} \mathrm{g}^{-1}\right)$ against Staphylococcus aureus during the ripening of Artisanal Minas Cheeses from Araxá was evaluated, and nisin reduced the $S$. aureus count to less than $1 \log \mathrm{CFU} \mathrm{g}^{-1}$ from the beginning to the end of ripening. Nisin slightly increased the $\mathrm{pH}$ and moisture content and decreased the fat content of Artisanal Minas Cheese from Araxá; however, with the lower bacteriocin concentration, these changes did not alter the ripening indexes, color, or texture parameters of the cheese, which changed only as a function of ripening. Nisin has the potential to limit the $S$. aureus growth in Artisanal Minas Cheese from Araxá, without changing the essential characteristics of this artisanal product.
\end{abstract}

Keywords: raw milk cheese; bacteriocin; pathogen; ripening; texture profile.

\section{RESUMO}

O queijo tradicional de Araxá é produzido com leite cru, o que representa um

1 Empresa de Pesquisa Agropecuária de Minas Gerais, Instituto de Laticínios Cândido Tostes, Rua Tenente Luiz de Freitas, 116, Santa Terezinha, 36045-560, Juiz de Fora, MG, Brasil. E-mail: denisesobral@ epamig.br

2 Universidade Federal de Minas Gerais, Instituto de Ciências Agrárias, Montes Claros, MG, Brasil.

3 Universidade Federal de Juiz de Fora, Faculdade de Medicina Veterinária, Juiz de Fora, MG, Brasil.

4 Universidade Federal de Viçosa, Departamento de Tecnologia de Alimentos, Viçosa, MG, Brasil.

* Autor para correspondência 
risco para a saúde dos consumidores. A ação da nisina (100 UI g g $\left.{ }^{-1} 400 \mathrm{UI} \mathrm{g}^{-1}\right)$ contra Staphylococcus aureus durante a maturação de Queijos Minas Artesanais de Araxá foi avaliada e a nisina reduziu a contagem de $S$. aureus para menos de $1 \log$ UFC $\mathrm{g}^{-1}$ do começo ao fim da maturação. A nisina aumentou ligeiramente o $\mathrm{pH}$ e o teor de umidade e diminuiu o teor de gordura do Queijo Minas Artesanal de Araxá; no entanto, com a menor concentração de bacteriocina, essas mudanças não alteraram os índices de maturação, cor ou textura do queijo, que variaram apenas em função da maturação. A nisina tem o potencial de limitar o crescimento de $S$. aureus em Queijo Minas Artesanal de Araxá, sem alterar as características essenciais deste produto artesanal.

Palavras-chave: queijo de leite cru; bacteriocina; patógeno; maturação; perfil de textura.

\section{INTRODUCTION}

Traditional Artisanal Minas Cheese is a semi-hard, enzymatically coagulated artisanal cheese, produced with raw bovine milk on a small scale by farms for many generations, using traditional practices (PINTO et al., 2011; CARDOSO et al., 2015). Within traditional Artisanal Minas Cheese, several varieties of cheeses are included and are classified according to the region where they are manufactured in the state of Minas Gerais (MG), Brazil (ARCURI et al., 2013). One of the most popular traditional Artisanal Minas Cheese is produced in the region of Araxá, MG, and like other traditional products, it has great social, economic, and cultural importance in this rural region.

Because Artisanal Minas Cheese from Araxá is produced from raw milk, it is a potential source of pathogens, such as Salmonella spp., Listeria monocytogenes, Escherichia coli, and Staphylococcus aureus (GADOTTI et al., 2014; MONTEL et al., 2014; PINTO et al., 2011; FLÓREZ; MAYO, 2015); therefore, it is a cause for public health concern. Many studies have found the survival of pathogenic bacteria in different traditional raw milk cheeses (EL GALIOU et al., 2015; PINTO et al., 2009; BRASIL, 1996; ANTONIOS et al., 2015; COKAL et al., 2012). Staphylococcal poisoning (contamination) is a perpetual threat to traditional raw milk cheeses because $S$. aureus is often transmitted to milk and cheese by milking animals with mastitis, human handling, milking equipment, and by environment, demonstrating the near ubiquity of this pathogen in this context (JAMALI et al., 2015; KADIROGLU et al., 2014; PINTO et al., 2011; FELICIO et al., 2015).

For these reasons, the maintenance of the cultural and social-economic importance of traditional Artisanal Minas Cheese from Araxá combined with its safety to consumers deserve special attention. Therefore, it is important to apply alternative technologies to ensure that the cheese keeps its physicochemical and microbiological characteristics, without representing a risk to consumers' health.

Nisin is an antimicrobial peptide produced by Lactococcus lactis that has been recognized as safe for food applications by the Joint Food and Agriculture Organization/ World Health Organization (FAO/WHO) Expert Committee on Food Additives (ZHAO et al., 2016). It has been used as a natural preservative for more than 50 years, and it is mainly used in cheeses to protect against gram-positive bacteria such as $S$. aureus (ZHAO et al., 2014). A previous study by our group demonstrated that nisin was able to reduce the $S$. aureus count of traditional Serro cheese with minimum changes in its 
physicochemical and texture characteristics (PINTO et al., 2011). Other recent studies have revealed the efficiency of nisin in controlling pathogens in cheeses, without changing the essential characteristics of these cheeses (MALHEIROS et al., 2012; GADOTTI et al., 2014; FELICIO et al., 2015).

Therefore, the aim of this work was to evaluate the effect of nisin against $S$. aureus in traditional Artisanal Minas Cheese from Araxá during 60 days of ripening, as well as to assay the influence of the bacteriocin on physicochemical and texture characteristics of the cheese.

\section{MATERIAL AND METHODS}

Artisanal Minas Cheeses from Araxá (1000 g) were produced following traditional practices of the region, with raw milk from three different farms collected with inadequate precautions in milking, hygiene, and handling, resulting in milk with high counts of $S$. aureus.
Commercial preparation of nisin $\left(\mathrm{Chrisin}^{\circledR}\right.$, Chr. Hansen A/S, Hørsholm, Denmark; $2.5 \%, \mathrm{w} / \mathrm{w}$ ) was added during the cheese manufacturing to obtain a final concentration of 100 and $400 \mathrm{IU} \mathrm{mL}^{-1}$, based on nisin levels used against $S$. aureus in Artisanal Minas Cheese from Serro (PINTO et al., 2011) (Figure 1). A cheese without nisin was also manufactured under the same conditions as a control sample. All cheeses were ripened at room temperature, on wood shelves, without relative humidity of air control.

$S$. aureus counts were determined in the milk used for cheese production, in the curd immediately after coagulation, and in the cheese during the ripening period (at 3 , 7, 14, 30, 45, and 60 days after production) by using Petrifilm 3M Rapid S. aureus (RSA) Count Plates (AOAC 981.15) according to the manufacturer's recommendations.

Samples of Artisanal Minas Cheese from Araxá were analyzed for moisture, fat, protein, chloride, and total nitrogen (TN) contents following the official methods

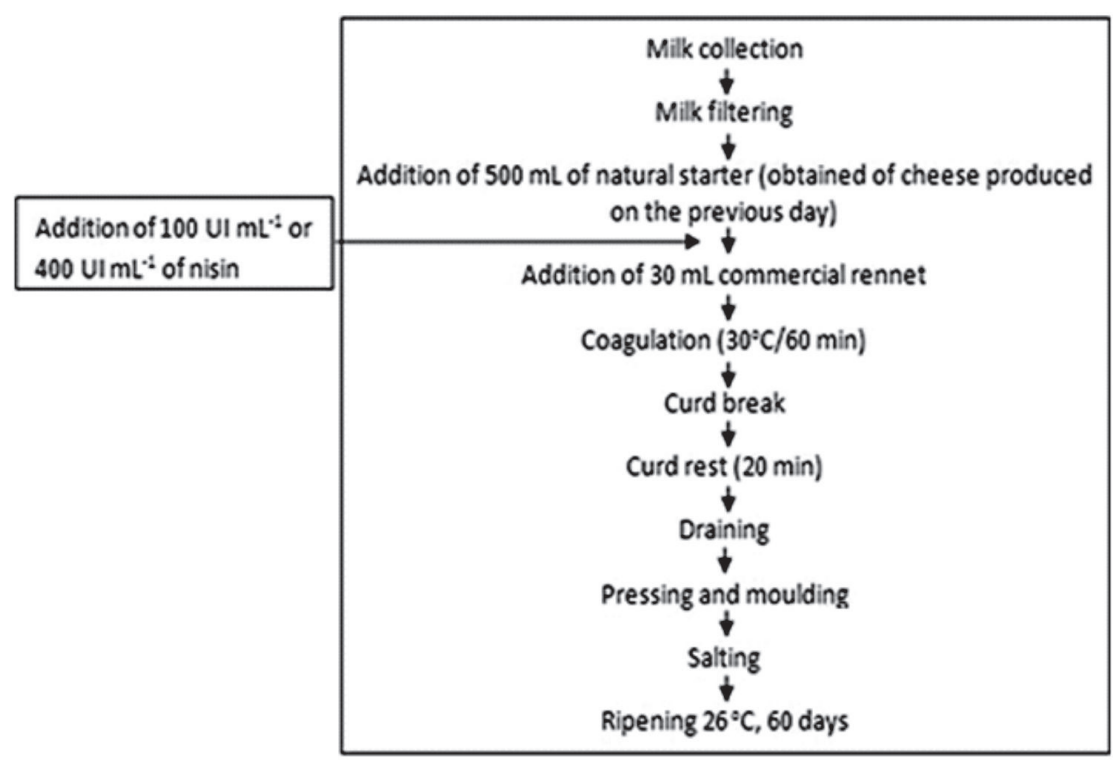

Figure 1 - Schematic flowchart of traditional production of Artisanal Minas Cheese from Araxá 
established by the Brazilian government (BRASIL, 2006). The protein content was calculated by multiplying $\mathrm{TN}$ by a factor of 6.38. The $\mathrm{pH}$ was measured using a Tec-2 Tecnal pH meter (Tecnal, Piracicaba, SP, Brasil) at 20 to $30{ }^{\circ} \mathrm{C}$ (APHA, 2001). The determination of water activity was carried out with an Aqualab water activity meter (model series CX2 T, Decagon Devices, Pullman, WA, USA). Non-protein-nitrogen (NPN) content was determined using the trichloroacetic acid technique (GAO et al., 2015).

The ripening extension index represents the degradation of casein or nitrogen originating from organic material and was quantified by the ratio (\%) of soluble nitrogen at $\mathrm{pH} 4.6$ and the TN. The ripening depth index was obtained from the ratio of NPN to TN (CERUTI et al., 2014). All analyses were carried out in triplicate, at 3, 7, 14, 30, 45, and 60 days of ripening.

The texture profile analysis (TPA) of Artisanal Minas Cheese from Araxá was carried out in an Instron Universal Testing Machine model 3367 (Instron Ltd., Norwood, MA, USA). Pre-test, test, and post-test speeds of $1 \mathrm{~mm} \mathrm{~s}^{-1}$ were used, with a compression distance of $40 \%$ from the top of the sample. It was used a cylindrical probe of $55 \mathrm{~mm}$ in diameter and a charge cell of $1 \mathrm{kN}$, which was moved perpendicularly through cylindrical cheese samples $(25 \mathrm{~mm}$ diameter and 35 $\mathrm{mm}$ height) that were randomly collected from the whole artisanal Minas cheese from Araxá cheese. The resistance exerted by the samples was automatically registered and provided data to calculate the firmness $(\mathrm{N})$, fracturability $(\mathrm{N})$, chewiness $(\mathrm{N})$, springiness, and cohesiveness based on a strength $(\mathrm{N}) \times$ time (s) curve using Blue Hill 2.0 software (Instron, Norwood, Massachusetts, USA).

The color of the cheeses was evaluated using a HunterLab Model ColorQuest II colorimeter (Hunter Associates Laboratory,
Inc., Reston, VA, USA). $L^{*}, a^{*}$, and $b^{*}$ values were read from the samples. The $L^{*}$ value is a measure of lightness that ranges between 0 and 100. Positive or negative changes in the $a^{*}$ value correspond to increases in the red or green color proportions, respectively, while the $b^{*}$ parameter varies from blue to yellow. Samples were taken eight times from different points on a piece of Artisanal Minas Cheese from Araxá. All analyses were carried out in triplicate, with cheese samples taken at day $3,7,14,30,45$, and 60 of ripening.

The experiments were carried out triplicate using a block randomized design with a factorial scheme (time $\times$ nisin concentrations). The decimal logarithms of $S$. aureus counts were subjected to regression analysis. The physicochemical and TPA results at each time point were evaluated by Analysis of Variance (ANOVA), using the Tukey test to compare means. The level of significance was set at $\mathrm{p}<0.05$. The analyses were performed using Minitab 14 statistical software (MINITAB INC., 2003).

\section{RESULTS AND DISCUSSION}

The ability of nisin to control staphylococcal growth is important to ensure the safety of raw milk cheeses such as Artisanal Minas Cheese from Araxá. There was a strong reduction $(p<0.05)$ in the $S$. aureus count to less than $1 \log \mathrm{CFU}$ $\mathrm{g}^{-1}$ in cheeses treated with both bacteriocin concentrations (100 IU mL-1 and $400 \mathrm{IU} \mathrm{mL}^{1}$ ) during 60 days of ripening, while cheese without nisin showed high bacteria counts that decreased over the ripening time (Figure 2).

This behavior can be explained by the combined effect of $\mathrm{pH}$, the decrease in $\mathrm{A}_{\mathrm{w}}$ and the production of compounds such as organic acids and bacteriocin by lactic bacteria (PINTO et al., 2011, 2009; KADIROGLU et al., 2014). However, is important to emphasize that by day 7 of ripening, the $S$. 
aureus count in control cheese reached almost $5 \log \mathrm{CFU} \mathrm{g}^{-1}$, presenting the potential to produce enterotoxins (CARMO et al., 2002; POLI et al., 2007) the sanitary services of the Health Board in the cities of Manhuaçu and Passa-Quatro, Minas Gerais, Brazil, were notified of two food poisoning outbreaks involving a total of 378 individuals. In the first outbreak, 50 individuals became ill after eating Minas cheese. The symptoms of food poisoning (diarrhoea, vomiting, dizziness, chills, and headaches) and thus representing a risk to consumers' health.

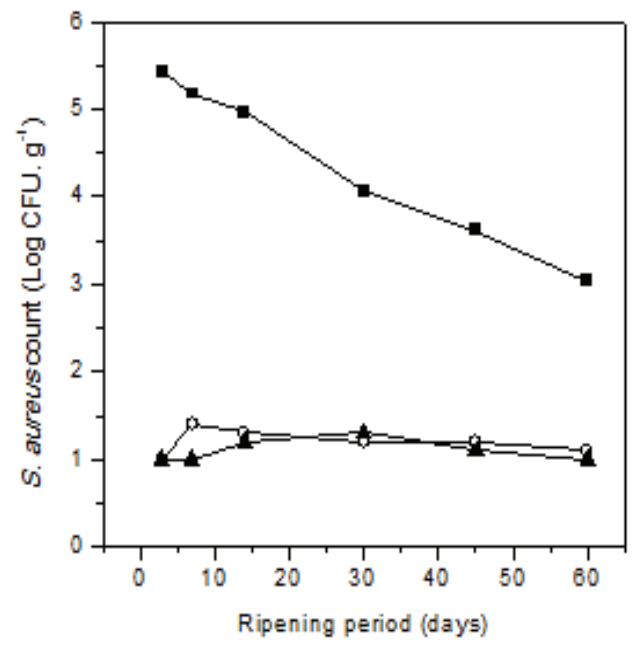

Figure 2 - Survival of $S$. aureus in Artisanal Minas Cheese from Araxá manufactured with nisin in different concentrations: ( $\mathbf{a})$ no nisin; (०) $100 \mathrm{IUmL}^{-1}$; and ( $\boldsymbol{\Delta}$ ) $400 \mathrm{IUmL}^{-1}$

The nisin effect against $S$. aureus from raw milk of the Araxá region was much higher than that found for Artisanal Minas Cheese from Serro (PINTO et al., 2011), even at a low concentration of $100 \mathrm{IU} \mathrm{mL}^{-1}$, suggesting that $S$. aureus from the Araxá region was more sensitive to nisin than $S$. aureus from the Serro region. This result is important because exposure of bacteria to sub-minimal inhibitory concentrations of nisin can induce nisin-resistance (GARDE et al., 2004).
The composition and physicochemical properties of traditional cheeses are very important to maintain quality parameters and the characteristics that define traditional products, such as flavor and texture (ERCAN et al., 2011). Moisture, water activity, $\mathrm{pH}$, chloride, protein, and fat content were parameters evaluated and presented in Table 1. Nisin treatment affected moisture, $\mathrm{pH}$, and fat content of Artisanal Minas Cheese from Araxá cheeses. For each ripening time analyzed, there was an increase in $\mathrm{pH}$ of nisin-treated cheeses $(p<0.05)$, which indicates that nisin inhibited acid-producing microbiota in the cheese. Nisin is known to be highly active against gram-positive bacteria, including Lactobacillus spp. and Micrococcus (TONG et al., 2014), which produce lactic acid in cheese. In addition, nisin has no activity against yeasts, and the growth of this group is known to increase the $\mathrm{pH}$ of Artisanal Minas Cheeses (LIMA et al., 2009). However, the $\mathrm{pH}$ range obtained in cheeses over the entire ripening time was similar to $\mathrm{pH}$ values found in other traditional Artisanal Minas Cheeses (LIMA et al., 2008; MARTINS et al., 2015; MATA; VANETTI, 2012; PINTO et al., 2011).

The increase in the moisture content of Araxá cheeses caused by nisin $(\mathrm{p}<0.05)$ can be explained by the effect of the bacteriocin against some bacteria responsible for cheeses proteolysis. Therefore, more polypeptide chains were present in the cheese and more solvation water molecules remained around these macromolecules (PINTO et al., 2011). There was a decrease in fat content of cheeses as the ripening time increased, which was probably owing to the dilution effect caused by moisture increasing.

The indexes of extension ( $\% \mathrm{SN}_{\mathrm{pH}} 4,6$ $\mathrm{TN})$ and depth (\% $\left.\mathrm{SN}_{\mathrm{TCA} 12 \%} / \mathrm{TN}\right)$ of ripening are parameters related to primary (mainly due to action of residual coagulant) and secondary (mainly due to action of bacterial proteases and peptidases) proteolysis occurring in cheeses, respectively (DIEZHANDINO et 
Table 1 - Physicochemical properties of Artisanal Minas Cheese from Araxá during the ripening period as a function of nisin concentration*

\begin{tabular}{|c|c|c|c|c|c|c|c|}
\hline $\begin{array}{l}\text { Ripening } \\
\text { (days) }\end{array}$ & $\begin{array}{l}\text { Nisin } \\
\left(\mathrm{IU} \mathrm{mL}^{-1}\right)\end{array}$ & $\mathrm{pH}$ & Aw & $\begin{array}{l}\text { Chloride } \\
(\% \mathrm{w} / \mathrm{w})\end{array}$ & $\begin{array}{l}\text { Moisture } \\
(\% \mathrm{w} / \mathrm{w})\end{array}$ & $\begin{array}{l}\text { Fat } \\
(\% \mathrm{w} / \mathrm{w})\end{array}$ & $\begin{array}{l}\text { Protein } \\
(\% \mathrm{w} / \mathrm{w})\end{array}$ \\
\hline \multirow{3}{*}{3} & 0 & $5.06^{\mathrm{b}}$ & $0.97^{\mathrm{a}}$ & $1.79^{\mathrm{a}}$ & $56.74^{\mathrm{a}}$ & $20.60^{a}$ & $16.13^{\mathrm{a}}$ \\
\hline & 100 & $5.33^{\mathrm{b}}$ & $0.98^{a}$ & $1.58^{\mathrm{a}}$ & $56.71^{\mathrm{a}}$ & $20.10^{\mathrm{a}, \mathrm{b}}$ & $17.50^{\mathrm{a}}$ \\
\hline & 400 & $5.69^{a}$ & $0.98^{a}$ & $1.74^{\mathrm{a}}$ & $58.48^{b}$ & $19.83^{b}$ & $15.80^{\mathrm{a}}$ \\
\hline \multirow{3}{*}{7} & 0 & $4.92^{\mathrm{a}}$ & $0.97^{\mathrm{a}}$ & $1.99^{\mathrm{a}}$ & $50.13^{b}$ & $25.10^{\mathrm{a}}$ & $18.52^{\mathrm{a}}$ \\
\hline & 100 & $5.00^{\mathrm{a}}$ & $0.97^{\mathrm{a}}$ & $1.78^{\mathrm{a}}$ & $52.40^{\mathrm{a}}$ & $22.60^{\mathrm{b}}$ & $18.63^{\mathrm{a}}$ \\
\hline & 400 & $5.57^{\mathrm{a}}$ & $0.97^{\mathrm{a}}$ & $1.87^{\mathrm{a}}$ & $53.22^{\mathrm{a}}$ & $20.33^{c}$ & $19.17^{\mathrm{a}}$ \\
\hline \multirow{3}{*}{14} & 0 & $4.88^{c}$ & $0.98^{a}$ & $2.11^{\mathrm{a}}$ & $48.14^{\mathrm{a}}$ & $30.10^{\mathrm{a}}$ & $19.36^{\mathrm{a}}$ \\
\hline & 100 & $5.11^{\mathrm{b}}$ & $0.97^{\mathrm{a}}$ & $2.00^{\mathrm{a}}$ & $46.83^{b}$ & $27.93^{b}$ & $21.17^{\mathrm{a}}$ \\
\hline & 400 & $5.39^{a}$ & $0.97^{\mathrm{a}}$ & $1.95^{\mathrm{a}}$ & $47.90^{\mathrm{a}, \mathrm{b}}$ & $26.60^{b}$ & $21.59^{\mathrm{a}}$ \\
\hline \multirow{3}{*}{30} & 0 & $5.09^{\mathrm{b}}$ & $0.96^{\mathrm{a}}$ & $2.27^{\mathrm{a}}$ & $42.88^{b}$ & $32.93^{\mathrm{a}}$ & $21.54^{\mathrm{a}}$ \\
\hline & 100 & $5.17^{\mathrm{b}}$ & $0.96^{\mathrm{a}}$ & $2.20^{\mathrm{a}}$ & $42.27^{\mathrm{b}}$ & $30.00^{\mathrm{b}}$ & $22.58^{\mathrm{a}}$ \\
\hline & 400 & $5.68^{a}$ & $0.97^{\text {a }}$ & $2.21^{\mathrm{a}}$ & $44.00^{\mathrm{a}}$ & $29.67^{b}$ & $22.16^{\mathrm{a}}$ \\
\hline \multirow{3}{*}{45} & 0 & $5.11^{\mathrm{b}}$ & $0.93^{a}$ & $2.64^{\mathrm{a}}$ & $31.83^{c}$ & $35.93^{\mathrm{a}}$ & $25.85^{\mathrm{a}}$ \\
\hline & 100 & $5.07^{b}$ & $0.94^{\mathrm{a}}$ & $2.46^{\mathrm{a}}$ & $37.53^{\mathrm{a}}$ & $32.00^{\mathrm{b}}$ & $24.96^{\mathrm{a}}$ \\
\hline & 400 & $5.45^{b}$ & $0.94^{\mathrm{a}}$ & $2.47^{\mathrm{a}}$ & $34.18^{b}$ & $31.17^{b}$ & $26.76^{\mathrm{a}}$ \\
\hline \multirow{3}{*}{60} & 0 & $5.19^{a}$ & $0.91^{\mathrm{a}}$ & $2.48^{a}$ & $29.29^{c}$ & $38.00^{\mathrm{a}}$ & $27.32^{\mathrm{a}}$ \\
\hline & 100 & $5.22^{\mathrm{a}}$ & $0.92^{\mathrm{a}}$ & $2.70^{\mathrm{a}}$ & $32.56^{\mathrm{a}}$ & $33.50^{\mathrm{b}}$ & $27.54^{\mathrm{a}}$ \\
\hline & 400 & $5.41^{\mathrm{a}}$ & $0.90^{\mathrm{a}}$ & $2.55^{\mathrm{a}}$ & $30.39^{b}$ & $36.00^{\mathrm{c}}$ & $27.39^{\mathrm{a}}$ \\
\hline
\end{tabular}

* For each time in column 1, the averages followed by the same superscript letters did not differ significantly $(\mathrm{p} \geq 0.05)$ when compared by Tukey test.

al., 2015). These indexes provide important information about the texture and sensory characteristics of cheese.

The extension and depth of ripening increased over the ripening period $(60 \mathrm{~d})$ $(p<0.05)$; however, there was no effect of nisin concentration on proteolysis of Artisanal Minas Cheese from Araxá ( $\mathrm{p} \geq 0.05)$, as shown in Figure 3. These results indicate that nisin was effective against $S$. aureus, but that it did not inhibit endogenous lactic acid bacteria
(LAB) of Araxá cheese enough to change the cheese ripening profile, and that texture and sensory characteristics of cheese were likely maintained.

Texture profile analysis (TPA) is a very important tool to determine the quality of cheeses (CARVALHO et al., 2015; TUDOREANU; DUMITREAN, 2009). Pinto et al. (2011) performed the first TPA of traditional Serro cheese with or without nisin added and verified that the bacteriocin 
did not change most texture parameters of this traditional Minas cheese. However, it was not found at the literature a TPA of traditional Artisanal Minas Cheese from Araxá; therefore, these results may contribute to the characterization of Araxá cheese as of "Protected Designation of Origin." Furthermore, to ensure that nisin addition did not change the characteristics of traditional Artisanal Minas Cheese from Araxá, it was carried out a TPA of cheese samples in every ripening time analyzed during the entire ripening period $(60 \mathrm{~d})$. TPA results showed that firmness, fracturability, chewiness, and springiness changed as a function of ripening time $(\mathrm{p}<0.05)$ (Figure 4) but were not affected by the addition of nisin ( $\mathrm{p} \geq 0.05)$.

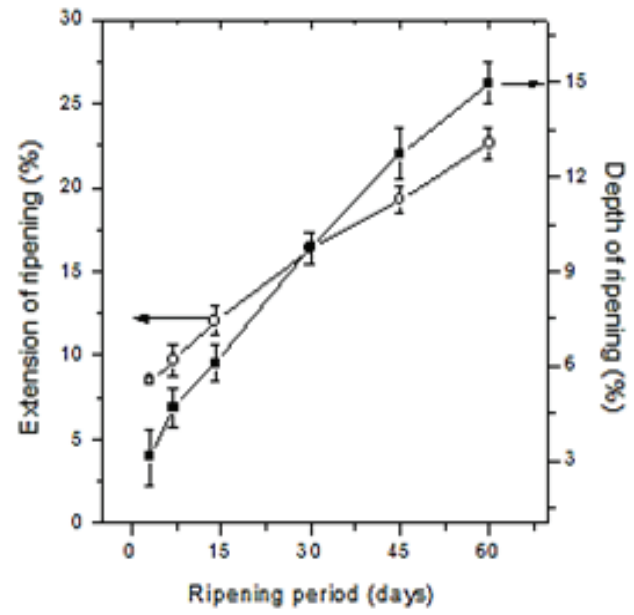

Figure 3 - Extension (०) and depth (ם) of ripening of Artisanal Minas Cheese from Araxá over 60 days of ripening

Firmness can be defined in sensory terms as the force needed to compress the cheese between the teeth or between the tongue and palate (YERLIKAYA; KARAGOZLU, 2011); this parameter is closely related to cheese proteolysis, which was not changed by bacteriocin addition, but was greatly influenced by ripening time. At the beginning of the ripening process, firmness is mainly influenced by the reduction in cheese moisture that causes an increase in firmness. However, at the end of the ripening period, proteolysis leads to a weaker protein network and cheese became softer (McSWEENEY, 2004; HORT; LE GRYS, 2001). Fracturability and chewiness behave similarly to firmness. Springiness, instead, showed contradictory behavior, with values that were reduced over the 45 days of ripening and only increased at the end of the process. Springiness is the rate at which deformed cheese returns to its undeformed condition in the course of chewing (YERLIKAYA; KARAGOZLU, 2011). As proteolysis increases over the ripening period, a slight proteolytic breakdown of the protein matrix may cause this springiness behavior (HORT; LE GRYS, 2001).

The only texture parameter that was exclusively increased by the nisin concentration is cohesiveness, which was about $15 \%$ higher when $400 \mathrm{IU} \mathrm{g}^{-1}$ of bacteriocin was used (from 0.67 at 0 and $100 \mathrm{IU} \mathrm{g}^{-1}$ of nisin to 0.82 at $400 \mathrm{IU} \mathrm{g}^{-1}$ of nisin). However, at the lower nisin concentration (100 IU g $\left.{ }^{-1}\right)$ there was no difference between Artisanal Minas Cheese from Araxá with and without bacteriocin, which indicates that the addition of a small amount of nisin did not change the textural features of artisanal Minas cheese from Araxá cheese.

To determine whether nisin causes any color change in Artisanal Minas Cheese from Araxá, it was evaluated color parameters of these cheeses with or without bacteriocin added over the 60 days of ripening. There was no change in the color of cheeses treated with nisin compared to the control cheese ( $\mathrm{p} \geq 0.05$ ); however, ripening time strongly affected the color of the cheese (Figure 5).

A decrease in $\mathrm{L}^{*}$ values was observed over the ripening period, suggesting that the lightness of Artisanal Minas Cheese from Araxá decreased during ripening. The $a^{*}$ and $b^{*}$ values were positive over the entire ripening process, indicating a reddish and 


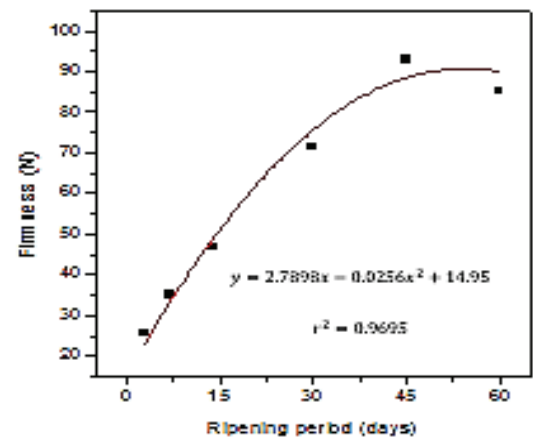

(a)

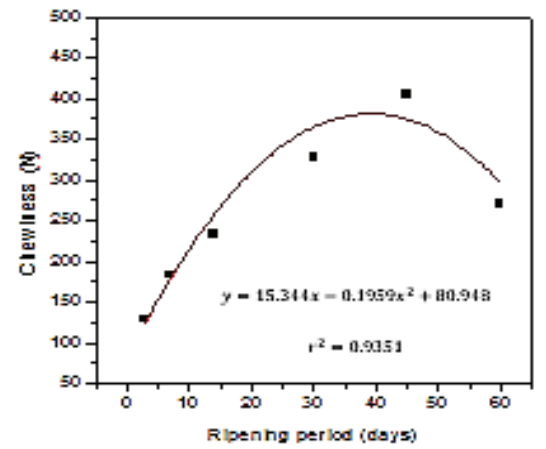

(c)

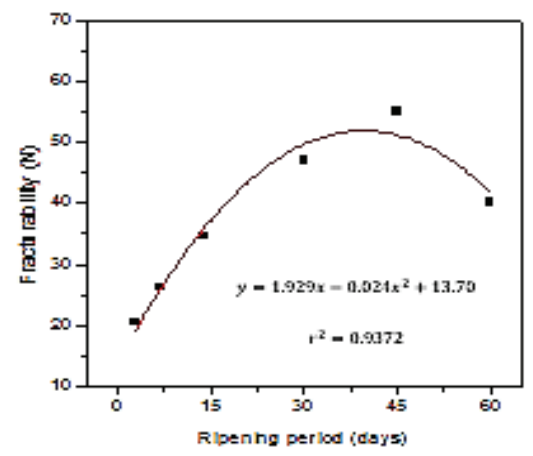

(b)

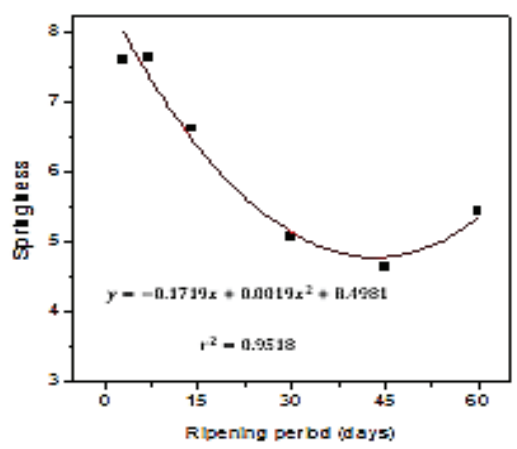

(d)

Figure 4 - Parameters from a texture profile analysis measured over 60 days of ripening of Artisanal Minas Cheese from Araxá. Parameters include (a) firmness, (b) fracturability, (c) chewiness, and (d) springiness. Each texture parameter was adjusted over the ripening period, based on a significant $(\mathrm{p}<0.05)$ quadratic model

yellowish direction, respectively, similar to results found by Pinto et al. (2011) for Artisanal Minas Cheese from Serro over 60 days of ripening. As ripening proceeded, the $\mathrm{H}^{*}$ value increased, indicating that Artisanal Minas Cheese from Araxá became more yellow-greenish; however, the $\mathrm{C}^{*}$ value remained almost constant at around $15^{\circ}$. Age-related changes in cheese color can be attributed to physicochemical changes caused by proteolysis in the cheese ripening process. This process alters protein hydration and, consequently, the free-water content and light-scattering properties of constituents of the cheese matrix (GÓMEZ-TORRES et al., 2015; PINTO et al., 2011).

\section{CONCLUSIONS}

The current study evaluated the ability of nisin, a Generally Recognized as Safe (GRAS) antimicrobial additive, to control $S$. 


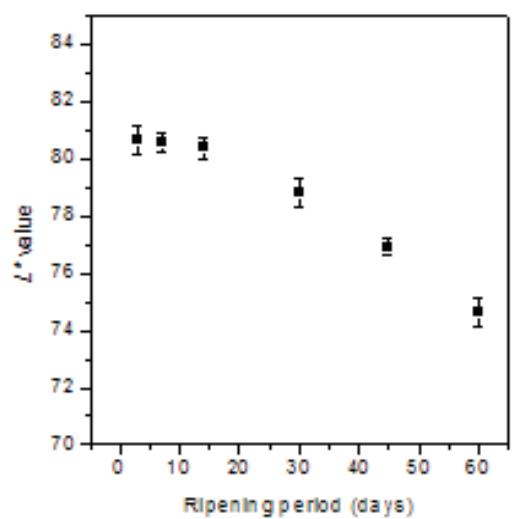

(a)

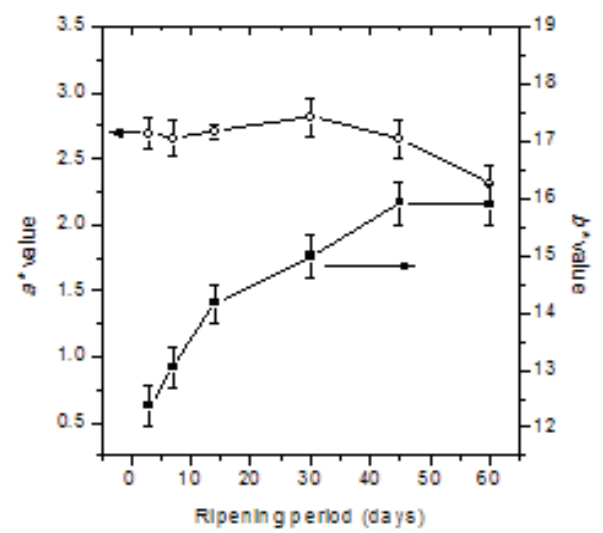

(b)

Figure 5 - Color changes in Araxá cheeses over 60 days of ripening: (a) L* value and (b) a* and $\mathrm{b}^{*}$ values

aureus in the Artisanal Minas Cheese from Araxá, a traditional Brazilian cheese. A low concentration of nisin $\left(100 \mathrm{IU} \mathrm{g}^{-1}\right)$ was found to be efficient in protecting against $S$. aureus in Artisanal Minas Cheese from Araxá, even at the beginning of the ripening process ( $3^{\text {rd }}$ day), which is very important due to consumers' demand for the freshest Araxá cheeses.

The addition of the bacteriocin resulted in no changes in color and very small changes in the physicochemical quality and texture of Artisanal Minas Cheese from Araxá, which indicated that nisin $\left(100 \mathrm{IU} \mathrm{g}^{-1}\right)$ did not markedly change the characteristics of this artisanal product.

In conclusion, nisin has the potential to be applied as a simple-to-use preventive against $S$. aureus growth in the manufacturing of traditional Artisanal Minas Cheese from Araxá, contributing to cheese safety without substantially affect the product identity. Obviously, nisin is only part of a preventive approach, and it should be used together with good manufacturing practices to achieve the best result.

\section{ACKNOWLEDGMENTS}

The authors thank Fundação de Amparo à Pesquisa do Estado de Minas Gerais (FAPEMIG), Conselho Nacional de Desenvolvimento Científico e Tecnológico (CNPq) and Pró-Reitoria de Pesquisa da Universidade Federal de Minas Gerais (PRPqUFMG) for financial support.

\section{REFERENCES}

ANTONIOS, Z. et al. Prevalence, genetic diversity and antimicrobial susceptibility profiles of Staphylococcus aureus isolated from bulk tank milk from Greek traditional ovine farms. Small Ruminant Research, v. 125 , p. $120-126,2015$. DOI: $10.1016 /$ j. smallrumres.2015.02.009.

ARCURI, E. F. et al. Determination of cheese origin by using $16 \mathrm{~S}$ rDNA fingerprinting of bacteria communities by PCR e DGGE: Preliminary application to traditional Minas cheese. Food Control, v. 30, n. 1, p. 1-6, 
2013. DOI: 10.1016/j.foodcont.2012.07.007.

BRASIL. MINISTÉRIO DA AGRICULTURA, PECUÁRIA E ABASTECIMENTO. SECRETARIA DE DEFESA AGROPECUÁRIA. Instrução Normativa $n^{\circ} 68$. Oficializa os Métodos Analíticos Oficiais Físico-Químicos, para Controle de Leite e Produtos Lácteos. Brasília. Diário Oficial da União. 12 de dezembro de 2006.

BRASIL. MINISTÉRIO DA AGRICULTURA, PECUÁRIA E ABASTECIMENTO. SECRETARIA DE DEFESA AGROPECUÁRIA. Portaria ${ }^{\circ}$ 146. Aprova os Regulamentos Técnicos de Identidade e Qualidade dos Produtos Lácteos. Diário Oficial da União. 7 de março de 1996.

CARDOSO, V. M. et al. The influence of seasons and ripening time on yeast communities of a traditional Brazilian cheese. Food Research International, v. 69, p. 331-340, 2015. DOI: 10.1016/j. foodres.2014.12.040.

CARMO, L. S. et al. Food poisoning due to enterotoxigenic strains of Staphylococcus present in Minas cheese and raw milk in Brazil. Food Microbiology, v. 19, n. 1, p. 9-14, 2002. DOI: 10.1006/fmic.2001.0444.

CARVAlHO, B. D. S. et al. Physicochemical and rheological properties of Prato cheese during ripening. African Journal of Biotechnology, v. 14, n. 24, p. 2028-2034, 2015. DOI: $10.5897 /$ ajb2015.14639.

CERUTI, R. et al. Effect of increased initial ripening temperature on the sensory characteristics of Reggianito cheese. International Journal of Dairy Technology, v. 67 , p. $539-546,2014$. DOI: $10.1016 /$ j. fm.2012.06.001.

COKAL, Y. et al. Presence of $L$. monocytogenes and some bacterial pathogens in two Turkish traditional foods, Mihalic cheese and Hosmerim dessert. Food Control, v. 26 , p. $337-340,2012$. DOI: $10.1016 / \mathrm{j}$. foodcont.2012.01.058.

DIEZHANDINO, I. et al. Microbiological, physico-chemical and proteolytic changes in a Spanish blue cheese during ripening (Valdeón cheese). Food Chemistry, v. 168, p. 134-141, 2015. DOI: 10.1016/j.foodchem.2014.07.039.

EL GALIOU, O. et al. Chemical and microbiological characteristics of traditional homemade fresh goat cheeses from Northern Morocco. Small Ruminant Research, v. 129, p. $108-113$, 2015. DOI: $10.1016 / \mathrm{j}$. smallrumres.2015.06.005.

ERCAN, D. et al. Physicochemical, textural, volatile, and sensory profiles of traditional Sepet cheese. Journal of Dairy Science, v. 94, p. 4300-4312, 2014. DOI: 10.3168/ jds.2010-3941.

FELICIO, B.A. et al. Effects of nisin on Staphylococcus aureus count and physicochemical properties of Minas Frescal cheese. Journal of Dairy Science, v. 98, p. 4364-4369, 2015. DOI: 10.3168/jds.20159520 .

FLÓREZ, A. B.; MAYO, B. Diversity and dynamics of antibiotic-resistant bacteria in cheese as determined by PCR denaturing gradient gel electrophoresis. International Journal of Food Microbiology, v. 214, p. 63-69, 2015. DOI: $10.1016 / \mathrm{j}$. ijfoodmicro.2015.07.027.

GADOTTI, C.; NELSON, L.; DIEZGONZALEZ, F. Inhibitory effect of combinations of caprylic acid and nisin on Listeria monocytogenes in queso fresco. Food Microbiology, v. 39, p. 1-6, 2014. DOI: 10.1016/j.fm.2013.10.007. 
GAO, P. et al. A non-protein nitrogen index for discriminating raw milk protein adulteration via the Kjeldahl method. Analytical Methods, v. 7, n. 21, p. 9166-9170, 2015. DOI: 10.1039/ c5ay01422k.

GARDE, S. et al. Fast induction of nisin resistance in Streptococcus thermophilus INIA 463 during growth in milk. International Journal of Food Microbiology, v. 96, p.165-72, 2004. DOI: 10.1016/j. ijfoodmicro.2004.03.023.

GÓMEZ-TORRES, N. et al. Impact of Clostridium spp. on cheese characteristics: microbiology, color, formation of volatile compounds and off-flavors. Food Control, v. 56, p. 186-194, 2015. DOI: 10.1016/j. foodcont.2015.03.025.

HORT, J.; LE GRYS, G. Developments in the textural and rheological properties of UK Cheddar cheese during ripening. International Dairy Journal, v. 11, p. 475481, 2001.

JAMALI, H. et al. Prevalence and antimicrobial resistance of Staphylococcus aureus isolated from raw milk and dairy products. Food Control, v. 54, p. 383-388, 2015. DOI: 10.1016/j.foodcont.2015.02.013.

KADIROGLU, P.; KOREL, F.; CEYLAN, C. Quantification of Staphylococcus aureus in white cheese by the improved DNA extraction strategy combined with TaqMan and LNA probe-based qPCR. Journal of Microbiological Methods, v. 105, p. 92-97, 2014. DOI: 10.1016/j.mimet.2014.06.022.

LIMA, C. D. L. C. et al. Microbiological, physical-chemical and sensory evaluation of a traditional Brazilian cheese during the ripening process. World Journal of Microbiology and Biotechnology, v. 24, n. 11 , p. $2389-2395,2008$. DOI: $10.1007 /$ s11274-008-9751-1.

LIMA, C. D. L. C. et al. Bactérias do ácido láctico e leveduras associadas com o queijode-minas artesanal produzido na região da Serra do Salitre, Minas Gerais. Arquivos Brasileiros de Medicina Veterinária e Zootecnia, v. 61, p. 266-272, 2009.

MALHEIROS, P. D. S. et al. Effect of liposome-encapsulated nisin and bacteriocinlike substance P34 on Listeria monocytogenes growth in Minas Frescal cheese. International Journal of Food Microbiology, v. 156, n. 3, p. $272-277,2012$. DOI: $10.1016 / \mathrm{j}$. ijfoodmicro.2012.04.004.

MARTINS, J. M. et al. Determining the minimum ripening time of artisanal Minas cheese, a traditional Brazilian cheese. Brazilian Journal of Microbiology, v. 46, n. 1, p. 219-230, 2015. DOI: 10.1590/S1517838246120131003 .

MATA, G. M. S. C.; VANETTI, M. C. D. Comparison of conventional and rapid methods for Salmonella detection in Artisanal Minas Cheese. Journal of Food Research, v. 1, n. 3, p. $178-183,2012$. DOI: $10.5539 /$ jfr.v1n3p178.

McSWEENEY, P. L. H. Biochemistry of cheese ripening. International Journal of Dairy Technology, v. 57, p. 127-144, 2004.

MONTEL, M. et al. Traditional cheeses: rich and diverse microbiota with associated benefits. International Journal of Food Microbiology, v. 177, p. 136-154, 2014. DOI: 10.1016/j.ijfoodmicro.2014.02.019.

PINTO, M. S. et al. The effects of nisin on Staphylococcus aureus count and the physicochemical properties of Traditional Minas Serro cheese. International Dairy 
Journal, v. 21, p. 90-96, 2011. DOI: 10.1016/j. idairyj.2010.08.001.

PINTO, M. S. et al. Survival of Listeria innocua in Minas Traditional Serro cheese during ripening. Food Control, v. 20, p. $1167-1170,2009$. DOI: $10.1016 / \mathrm{j}$. foodcont.2009.02.007.

POLI, A. et al. Detection of Staphylococcus aureus and enterotoxin genotype diversity in Monte Veronese, a Protected Designation of Origin Italian cheese. Letters in Applied Microbiology, v. 45, n. 5, p. 529-34, 2007. DOI: $10.1111 /$ j.1472-765X.2007.02224.x.

TONG, Z.; NI, L.; LING, J. Antibacterial peptide nisin: a potential role in the inhibition of oral pathogenic bacteria. Peptides, v. 60 , p. $32-40,2014$. DOI: $10.1016 / j$. peptides.2014.07.020.

TUDOREANU, L.; DUMITREAN, L. Texture profile analysis of some Romanian Pasta Filata cheese varieties (Caciocavallo cheese). Bulletin UASVM Agriculture, v. 66, n. 2, p. 512-517, 2009.

YERLIKAYA, O.; KARAGOZLU, C. Effects of ripening period on textural and sensory properties of Capper cheeses. Journal of Animal and Veterinary Advances, v. 10, n. 9, p. 1171-1176, 2011. DOI: 10.3923/ javaa.2011.1171.1176.

ZHAO, X. et al. In Vitro synergy of nisin and coenzyme Q0 against Staphylococcus aureus. Food Control, v. 46, p. 368-373, 2014. DOI: 10.1016/j.foodcont.2014.05.051.

ZHAO, X. et al. Analysis of the gene expression pro fi le of Staphylococcus aureus treated with nisin. Food Control, v. 59, p. 499-506, 2016. DOI: $10.1016 / \mathrm{j}$. foodcont.2015.06.018. 